\title{
Federal Reserve Policy viewed through a Money Supply Lens
}

Ibrahim Chowdhury and Andreas Schabert

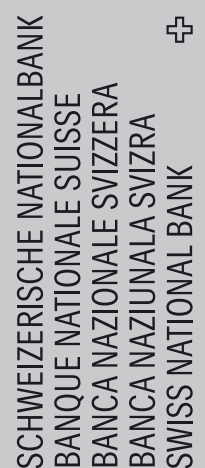

U

(1)

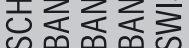

( 
The views expressed in this paper are those of the author(s) and do not necessarily represent those of the Swiss National Bank. Working Papers describe research in progress. Their aim is to elicit comments and to further debate.

ISSN $1660-7716$

๑ 2007 by Swiss National Bank, Börsenstrasse 15, P.0. Box, CH-8022 Zurich 


\title{
Federal Reserve Policy viewed through a Money Supply Lens ${ }^{1}$
}

\author{
Ibrahim Chowdhury ${ }^{2}$ \\ Swiss National Bank \\ Andreas Schabert ${ }^{3}$ \\ University of Dortmund and Tinbergen Institute
}

This version: January 3, 2007

\begin{abstract}
This paper examines whether the U.S. Federal Reserve has adjusted high-powered money supply in response to macroeconomic indicators. Applying ex-post and real-time data for the postwar period, we provide evidence that nonborrowed reserves responded to expected inflation and the output-gap. While the output-gap feedback has always been negative, the response of money supply to changes in inflation varies considerably across time. The inflation feedback is negative in the post-1979 period and positive, albeit smaller than one, in the pre-1979 period. Applying a standard macroeconomic model, these properties are shown to be consistent with a welfare maximizing policy, and to ensure equilibrium determinacy. Viewed through the money supply lens, the Fed has thus never allowed for endogenous fluctuations, which contrasts conclusions drawn from federal funds rate analyses.
\end{abstract}

JEL classification: E51, E52, E32.

Keywords: Nonborrowed reserves, monetary policy reaction functions, real-time data, determinacy

\footnotetext{
${ }^{1}$ The views expressed in this paper are those of the authors and do not necessarily reflect the views of any institution. The usual disclaimer applies. The authors are particularly grateful to an anonymous referee for helpful comments on an earlier draft. The authors would like to thank Stephane Adjemian, Katrin Assenmacher-Wesche, Roel Beetsma, Ben Craig, Stefan Gerlach, Dieter Nautz, Paul Mizen, Manfred Neumann, Hermann Remsberger, Axel Weber, Volker Wieland, and other seminar participants at the Bundesbank Conference in Eltville, October 2005, and at the Universities of Amsterdam, Frankfurt, and Mannheim.

${ }^{2}$ Swiss National Bank, Börsenstrasse 15, 8022 Zurich, Switzerland, Phone: +41 4463135 59, Fax: +41 4463139 80, e-mail: ibrahim.chowdhury@snb.ch

${ }^{3}$ University of Dortmund, Department of Economics, Vogelpothsweg 87, 44227 Dortmund, Germany.
} 


\section{Introduction}

This paper re-examines postwar U.S. Federal Reserve policy by looking at the supply of high-powered money at business cycle frequency. Our main objective is to disclose whether the well-established shift in the conduct of monetary policy between the pre-1979 (preVolcker) and the post-1979 (Vocker-Greenspan) period is mirrored in systematic adjustments of high-powered money. To this end, we examine the feedback from macroeconomic indicators to money supply and estimate forward-looking reaction functions for nonborrowed reserves. Given that the latter serves as the monetary instrument that implements particular interest rate targets (see Meulendyke, 1998), we expect that systematic changes of nonborrowed reserves and the federal funds rate are closely related.

In this context, our approach corresponds to the one of Clarida et al. (2000) and Orphanides (2001) who estimate forward-looking feedback rules for the federal funds rate. Our empirical analysis reveals substantial differences in the way the Federal Reserve has adjusted money supply in response to changes in macroeconomic indicators between the pre-1979 and the post-1979 period. While this phenomenon has been observed in the empirical literature on forward-looking interest rate rules, our theoretical analysis indicates that the alleged macroeconomic instability in the pre-1979 period has not been associated with multiple equilibria, as for example suggested by Clarida et al. (2000). In fact, by looking through the money supply lens the pre-Volcker policy was less anti-inflationary, but nevertheless ensured equilibrium determinacy.

The starting point of our analysis is that the supply of nonborrowed reserves rather than the federal funds rate is directly controlled by the Federal Reserve. Thus, policyinduced changes in intermediate or macroeconomic targets should be associated with changes in the supply of high-powered money. This view accords with Eichenbaum (1992) or Strongin (1995) who analyzed the effects of monetary policy shocks measured by unanticipated changes in nonborrowed reserves using vector autoregressions (VARs). Their identification of money supply shocks is based on the isolation of exogenous policy actions from systematic money supply adjustments. ${ }^{4}$ However, the implied reaction function for the supply of nonborrowed reserves has drawn much less attention than reaction functions for the federal funds rate.

Focussing on the federal funds rate, several studies have shown that its movements can be summarized by forward-looking reaction functions (see Woodford, 2003, for an overview). These reaction functions, which are often termed Taylor-rules, show that the federal funds rate has been adjusted in response to changes in expected inflation, the output-gap, and its own lag. Furthermore, shifts in the reactiveness of the federal funds rate have been taken as an indicator for shifts in the conduct of monetary policy. In

\footnotetext{
${ }^{4}$ Bernanke and Mihov (1998) and Christiano et al. (1999) also apply VARs to examine responses to monetary policy shocks which are identified with innovations to nonborrowed reserves.
} 
their seminal paper, Clarida et al. (2000) have found that the feedback from expected inflation to the federal funds rate has been less pronounced in the pre-1979 period than in the period after 1979, the year Paul Volcker's mandate as Chairman of the Board of Governors of the Federal Reserve System started.

By estimating a forward-looking reaction function for the growth rate of nonborrowed reserves for U.S. postwar data we provide evidence that money supply has also responded to changes in the expected inflation rate and the output-gap. In particular, we find that the growth rate of nonborrowed reserves has always responded negatively to a rise in the output-gap. In contrast, money supply responses to changes in expected inflation exhibit a qualitative difference between the pre-1979 and the post-1979 period. The inflation feedback is negative for the Volcker-Greenspan era, while it is positive for the pre-Volcker era. These results indicate that Federal Reserve policy in the pre-Volcker period has less aimed to stabilize inflation than in the Volcker-Greenspan period. The qualitative shift in the money supply behavior is further found to be robust for various specifications of the forward-looking component (inflation) and for the output-gap.

To further assess the robustness of our results, we account for an important criticism raised by several authors, namely, that monetary policy assessments based on ex post data might lead to biased results (e.g. Orphanides, 2001, 2002, 2004; Boivin, 2006). Specifically, estimations of forward-looking reaction functions for the federal funds rate with real-time data by Orphanides (2004) indicate that interest rate adjustments to inflation forecasts hardly differed between the pre-1979 period and the post-1979 period. To account for this argument, we estimate money supply reaction functions using the so-called Greenbook forecasts (which the staff of the Federal Reserve prepared for the Federal Reserve Open Market Committee meetings). Notably, our estimates based on real-time data do not qualitatively differ from our ex post data-based estimates.

Hence, viewing Federal Reserve policy through a money supply lens points to a clear regime shift in the conduct of monetary policy, regardless whether the assessment is based on ex post data or real-time data. This finding is of particular interest given that the empirical literature on forward-looking interest rate reaction functions is less clear on the shift of U.S. monetary policy in the 1980s. The real-time evidence by Orphanides (2004), for example, contrasts Clarida et al.'s (2000) results based on ex post data by pointing to a forward-looking approach to policy consistent with strong reactions to inflation forecasts both before and after Volcker's appointment as Chairman.

In the theoretical part of the paper we apply a consensus macroeconomic model where monetary policy is summarized by a state contingent money supply, i.e. a forward-looking money growth reaction function. This model, which is otherwise identical to the standard New Keynesian model (see Clarida et al., 1999, 2000), is applied to derive characteristics for money supply reaction functions consistent with a welfare maximizing policy and with equilibrium determinacy. As the central principle it is shown that the money growth 
rate should not rise with (expected) inflation by more than one for one in order to avoid indeterminacy. Thus, money supply should satisfy a restriction on the inflation feedback which corresponds to the well-known "Taylor-principle" (see Woodford, 2001). ${ }^{5}$ Applying this condition to assess the stability implications of the estimated money supply reaction functions, we find that Federal Reserve policy always ensured uniqueness of a rational expectations equilibrium. Notably, this result holds for both policy regimes regardless whether the point estimates for the feedback coefficients are based on real-time or revised data.

Concisely, we cannot confirm Clarida et al.'s (2000) hypothesis that Federal Reserve policy in the pre-1979 period failed to pin down an unique rational expectations equilibrium. Put differently, our theoretical analysis indicates that Federal Reserve policy has never allowed for expectations driven inflation fluctuations. Nonetheless, our results confirm that there has been a shift in the Fed's stance towards the stabilization of inflation relatively to the output-gap.

The remainder of the paper is set out as follows. Section 2 provides the empirical analysis. Section 3 briefly describes the macroeconomic model and characterizes efficient money supply. Further, it presents closed form determinacy conditions for money supply reactions functions. Section 4 concludes.

\section{Postwar Federal Reserve money supply}

It has become common practice in theoretical and empirical analysis to characterize monetary policy by feedback rules for a short-run interest rate, which serves as the central bank's operating target. Empirical studies by Taylor (1999), Clarida et al. (2000) or Orphanides (2001) have shown that the systematic component of postwar U.S. monetary policy can be described by state contingent adjustments of the federal funds rate. However, in order to control the interest rate, the Federal Reserve adjusts quantities of high-powered money in open market operations. Put differently, sales and purchases of nonborrowed reserves in open market operations actually serve as monetary instruments, which are used to implement particular interest rate targets (see Meulendyke, 1998). ${ }^{6}$

In this Section, we examine whether U.S. monetary policy can alternatively be characterized by systematic adjustments of the monetary instrument, i.e., nonborrowed reserves.

\footnotetext{
${ }^{5}$ When an interest rate policy is active, i.e., satisfies the Taylor-principle, the real interest rate increases with inflation and equilibrium determinacy is ensured. Correspondingly, the growth rate of real balances should decrease with inflation in order to avoid indeterminacy (see Schabert, 2006).

${ }^{6}$ By purchasing or selling securities through open market operations the Federal Reserve adjusts the supply of nonborrowed reserves. In addition, the Federal Reserve can supply reserves to the banking system by lending through the Federal Reserve discount window. Reserves obtained through this channel are known as borrowed reserves. In general, banks are expected to make use of the discount window borrowing only after drawing on all other available sources of funds. With the development of financial markets it has become more feasible and efficient to provide reserves primarily through open market operations. Accordingly, discount window lending has accounted for a relatively small part of total reserves.
} 
Corresponding to studies on interest rate feedback rules, we thereby aim to unveil how the monetary policy stance systematically changes with (expected) changes in core macroeconomic variables, i.e., inflation and the output-gap. Further, we want to examine if there exists a shift in the Federal Reserve's money supply that relates to the well-established shift in the federal funds rate behavior, which has been interpreted as an indication that Federal Reserve policy in pre-1979 period has been less stabilizing than in the post-1979 period.

\subsection{Evidence from vector autoregressions}

The behavior of nonborrowed reserves and the federal funds rate has been examined in a number of studies. Studies by Hamilton (1997), Thornton (2001), or Carpenter and Demiralp (2006) build on comprehensive specifications of the market for federal reserves, focussing on the behavior of the federal funds rate and money supply on the basis of high frequency data (daily and monthly frequency). One central question in this literature relates to the existence of a liquidity effect, i.e., a negative relation between the supply of reserves and the change in the federal funds rate. While the existence of such a relationship seems to be relevant for the control of the federal funds rate, there is no clear evidence in favor of a liquidity effect (see Leeper and Gordon, 1992, or Thornton, 2001).

Unlike these studies, our analysis of monetary policy draws on data at business cycle frequencies. It is widely known that the behavior of reserves at higher frequency can be distorted by a mismatch between the Federal Reserve's forecast of the supply of reserves and the actual supply of reserves perceived in the banking system. Even though the Federal Reserve attempts to sterilize unanticipated money market distortions on a daily basis, it cannot fully neutralize the arising mismatch. At lower frequencies, however, changes in the supply of nonborrowed reserves should primarily reflect changes in the monetary policy stance. Hence, distortions arising through non-monetary policy effects at higher frequencies are largely neutralized at lower frequency.

Another strand of the literature, which is more related to the purpose of this paper, has focussed on the monetary transmission mechanism at lower frequency, where monetary policy shocks are identified with changes in nonborrowed reserves. Structural vector autoregressions (SVARs) in Eichenbaum (1992), Strongin (1995), and Christiano et al. (1999) show that unanticipated changes in the supply of nonborrowed reserves yield changes in real activity and aggregate prices. In order to identify monetary policy shocks, exogenous policy changes have to be isolated from endogenous reactions of the monetary policy stance. Hence, the SVARs contain a reaction function for nonborrowed reserves, which describes how the Federal Reserve has adjusted money supply contingent on changes in macroeconomic variables of interest.

To provide some VAR-based evidence on shifts in the money supply behavior, we esti-

mate a reduced-form VAR using quarterly data for the U.S. and compute impulse response 
functions for nonborrowed reserves. The objective of this exercise is to examine how nonborrowed reserves vary systematically to changes in main macroeconomic indicators across different sample periods. Our estimated VAR closely relates to the benchmark specification of Christiano et al. (1999) and includes the log of real GDP $(Y)$, the log of the implicit GDP deflator $(P)$, the change in an index of commodity prices $(C P)$, the federal funds rate $(F F)$, the $\log$ of total reserves $(T R)$ and the $\log$ of nonborrowed reserves plus extended credit $(N B R)$, respectively. The overall sample period covers the time horizon 1960 Q1 to 1999 Q4.

We additionally estimate the VAR for two sub-samples, namely, for the periods before and after 1979, the year Paul Volcker started the mandate as Chairman of the Board of Governors of the Federal Reserve System. The first subsample covers the period 1960 Q1 to 1979 Q2 (pre-Volcker period), and the second subsample spans the period 1982 Q4 to 1999 Q4 (Volcker-Greenspan period). ${ }^{7}$ According to a widespread view Federal Reserve policy has been less well managed in the pre-Volcker period than in the Volcker-Greenspan period. According to this view, Federal Reserve policy during the pre-Volcker period has been less anti-inflationary than after Paul Volcker's appointment as Fed Chairman (see Friedman and Kuttner, 1996, or Taylor, 1999). Several empirical studies have highlighted this shift in the conduct of U.S. monetary policy. Specifically, Clarida et al. (2000), who estimated a forward-looking reaction function for the federal funds rate, established a significant difference in the way the federal funds rate has responded to changes in macroeconomic indicators.

For all VAR estimations, standard lag selection criteria recommended a lag length of 4 quarters and we apply structural identifications schemes to identify exogenous monetary policy shocks. A specific identification scheme, which, for example, is used by Christiano et al. (1999), is based on a Cholesky decomposition combined with a Wold ordering of the variables where nonborrowed reserves can react to contemporaneous changes in the remaining variables. Here, we adopt their identification scheme and compute impulse responses to innovations in macroeconomic variables, to demonstrate how the responses of nonborrowed reserves changed over time.

\footnotetext{
${ }^{7}$ Although Volcker was appointed Chairman of the Board of Governors of the Federal Reserve System in 1979, we refrain from including the first three years of his mandate in the sample period because this might lead to biased estimates for the Volcker-Greenspan period (see Clarida et al. 2000). Indeed, for a brief period at the start of the Volcker era, the Fed seemed to pursue a policy of non-borrowed reserves targeting (see Goodfriend, 1991).
} 
Figure 1: Responses of Nonborrowed Reserves

Panel A: Full Sample Period: 1960 Q1 to 1999 Q4

Response to Cholesky One S.D. Innovations \pm 2 S.E.
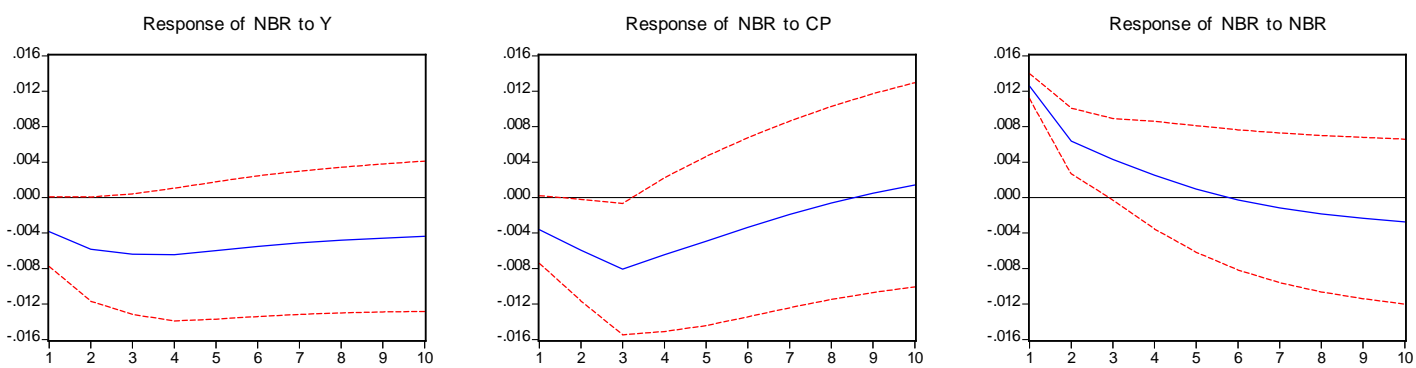

Panel B: Pre-Volcker Period: 1960 Q1 to 1979 Q2

Response to Cholesky One S.D. Innovations \pm 2 S.E.
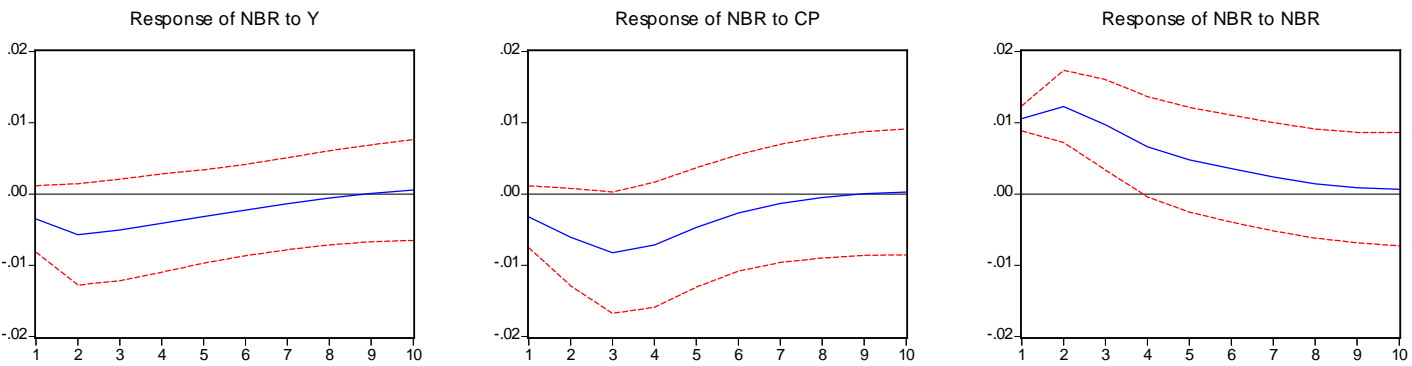

Panel C: Volcker-Greenspan Period: 1982 Q4 to 1999 Q4

Response to Cholesky One S.D. Innovations \pm 2 S.E.
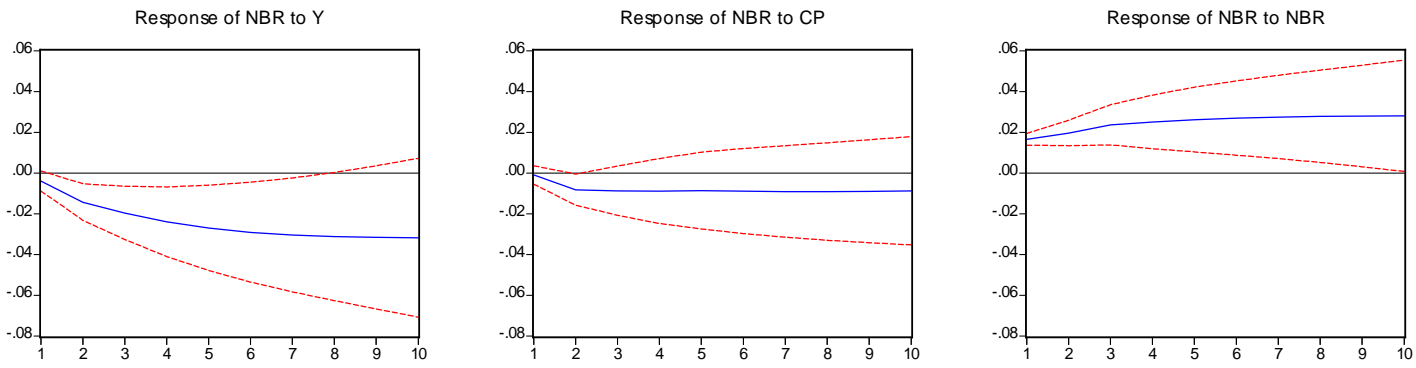

Figure 1 presents impulse responses of nonborrowed reserves to innovations in key macroeconomic variables, such as $(Y, C P$, and $N B R)$. Overall, the impulse response functions suggest that the supply of nonborrowed reserves is reduced in response to positive innovations in real activity and commodity prices. Yet, the first column shows that only in the Volcker-Greenspan period nonborrowed reserves responded to changes in real activity in a significant way. ${ }^{8}$ This difference is less pronounced for the responses to commodity

\footnotetext{
${ }^{8}$ The dotted lines present a two standard error band, computed with the Monte Carlo method, spanning a $95 \%$ confidence interval.
} 
price innovations (second column), though the point estimates suggest a more persistent response in the Volcker-Greenspan period. Finally, nonborrowed reserves always exhibit a significant and positive response to own innovations, while the persistence is most pronounced in the Volcker-Greenspan period.

\subsection{Money supply reaction functions}

The VAR estimates already disclose differences in Federal Reserve money supply adjustments between the pre- and the post-1979 periods. In order to provide a more transparent view on the systematic part of money supply we apply a single equation approach, which is now widely used to measure systematic central bank adjustments of a short-run interest rate. Specifically, we estimate a reaction function for the growth rate of nonborrowed reserves, which closely relates to the specification of the reaction function for the federal funds rate in Clarida et al. (2000). Thus, we assume that the growth rate of nonborrowed reserves responds to expected inflation and the output-gap in the following way:

$$
\mu_{t}=\rho \mu_{t-1}+\mu_{\pi} E_{t}\left\{\pi_{t+n}\right\}+\mu_{y} x_{t}+\varepsilon_{t},
$$

where $\mu_{t}$ denotes the annualized growth rate of nonborrowed reserves, $x_{t}$ the output-gap measure, and $E_{t}\left\{\pi_{t+n}\right\}$ is the expected inflation rate in $t+n$. The error term $\varepsilon_{t}$ is assumed to be independently and identically distributed (iid) Gaussian.

The specification (1) evidently differs from the previous VAR-based specification. First, the single-equation approach is based on a parsimonious specification in growth rates, which allows for a more comprehensible interpretation of the estimated coefficients, but nonetheless is consistent with a log-level VAR specification. Second, unlike in the VAR approach, where the impact of expected future inflation is indirectly considered by the commodity price index, expected inflation is now modelled explicitly. Third, in line with interest rate feedback rules output-gap instead of output is considered as an additional explanatory variable. Finally, we chose the narrowest monetary aggregate and carry out all estimations using nonborrowed reserves as opposed to nonborrowed reserves plus credit, which has been used in the previous section.

We first estimate (1) over a sample period which spans forty years of Federal Reserve policy. All data are obtained from the Federal Reserve Bank of St. Louis and are of quarterly frequency, spanning the horizon 1960:1-1999:4. Our benchmark inflation measure is based on the GDP deflator and is defined as the annualized percentage change in the price level between two subsequent quarters. Alternatively, we also consider consumer price inflation. output-gap is defined as the percent deviation between actual GDP and potential GDP as constructed by the Congressional Budget Office (CBO). We additionally allow for two alternative output-gap measures: (a) deviation of (log) GDP from a fitted quadratic function of time; and (b) the deviation of the unemployment rate from a similar time trend. For the future inflation rate we consider a horizon of one quarter in our benchmark 
estimations $(n=1)$. We further allow for longer inflation horizons and report estimates based on a forward-looking horizon of four quarters $(n=4)$.

A widely used technique for estimating an equation of above nature is Generalized Method of Moments (GMM). The starting point of any GMM estimation is a theoretical relation that the parameters should satisfy, which is described by orthogonality conditions between some function of the parameters $f(\theta)$ and a set of instrumental variables $z_{t}$ :

$$
E_{t}\left(f(\theta) z_{t}\right)=0
$$

where $\theta$ contains the parameters to be estimated. Let $f(\theta)=\mu_{t}-\rho \mu_{t-1}-\mu_{\pi} E_{t}\left\{\pi_{t+n}\right\}-$ $\mu_{y} x_{t}$ and assuming rational expectations we can write

$$
E_{t}\left\{\left(\mu_{t}-\rho \mu_{t-1}-\mu_{\pi} \pi_{t+n}-\mu_{y} x_{t}\right) z_{t}\right\}=0
$$

which provides the basis for estimating the parameter vector $\left(\rho, \mu_{\pi}, \mu_{y}\right) .^{9}$ For all estimations the vector of instruments includes four lags of the growth rate of nonborrowed reserves, output-gap, and inflation. Since not all current information may be available to the public at the time they form expectations, contemporary variables are not used as instruments.

The estimation results for the full sample are summarized in Table 1. All specifications are associated with a significant and pronounced autocorrelation coefficient $\rho$. Turning to the output-gap, a widening of the output-gap leads to a negative response in the supply of nonborrowed reserves. The estimated coefficient $\mu_{y}$ is statistically significant and lies in a range between -0.25 for the inflation rate based on the GDP deflator and -0.29 for CPI inflation. In contrast, there is no statistically significant relationship between the growth rate of nonborrowed reserves and expected inflation for both inflation measures over the full sample period, including the real-time data specification "Greenbook" (which we discuss below). While the estimated coefficient $\mu_{\pi}$ on expected inflation is positive, albeit close to zero, it is not found to be statistically significant. A common view on stabilizing monetary policy, would certainly suggest a negative relationship between the supply of nonborrowed reserves and expected inflation: Higher expected inflation should induce an anti-inflationary monetary policy to reduce the supply of nonborrowed reserves (see section 3). The above reported estimation results, however, seem to proof us wrong. An explanation for this finding might relate to the considered sample period, which does not distinguish between distinct periods of Federal Reserve policy. To this end we carry out sub-sample estimations for the money supply reaction function.

\footnotetext{
${ }^{9}$ The parameter estimates are obtained using a criterion function, that is of the following nature: $J(\theta)=(f(\theta) z)^{\prime} W(f(\theta) z)$, where $W$ is a weighting matrix.
} 
Table 1. Estimation Results for the Sample Period: 1960 - 1999

\begin{tabular}{ccccccc}
\hline & \multicolumn{2}{c}{ GDP Deflator } & \multicolumn{2}{c}{$C P I$} & \multicolumn{2}{c}{ Greenbook } \\
& $n=1$ & $n=4$ & $n=1$ & $n=4$ & $n=1$ & $n=4$ \\
\hline \hline$\widehat{\rho}$ & $0.88^{*}$ & $0.89^{*}$ & $0.88^{*}$ & $0.88^{*}$ & $0.90^{*}$ & $0.91^{*}$ \\
& $(0.03)$ & $(0.03)$ & $(0.03)$ & $(0.03)$ & $(0.03)$ & $(0.03)$ \\
$\widehat{\mu}_{\pi}$ & 0.07 & 0.06 & 0.04 & 0.04 & 0.03 & -0.04 \\
& $(0.06)$ & $(0.06)$ & $(0.04)$ & $(0.05)$ & $(0.06)$ & $(0.08)$ \\
$\widehat{\mu}_{y}$ & $-0.25^{*}$ & $-0.26^{*}$ & $-0.29^{*}$ & $-0.29^{*}$ & $-0.75^{*}$ & -0.45 \\
& $(0.11)$ & $(0.11)$ & $(0.11)$ & $(0.11)$ & $(0.28)$ & $0.32)$ \\
$R^{2}$ & 0.70 & 0.70 & 0.70 & 0.70 & 0.44 & 0.60 \\
$J$ & 0.62 & 0.61 & 0.58 & 0.57 & 0.69 & 0.69 \\
\hline
\end{tabular}

Notes: Figures in parentheses below coefficient estimates denote standard errors. Coefficients which are significant at the 5 percent level are marked with "*". $R^{2}$ denotes the coefficient of determination; $J$ is a test statistic for the null hypothesis that the overidentifying restrictions are satisfied. For the latter we only report $p$-values.

The first period we examine, covers the time horizon 1960:01 to 1979:2 and is referred to as the pre-Volcker era. We further explore monetary policy in the Volcker-Greenspan era, which covers the time horizon 1982:4 to 1999:4. Table 2 summarizes the results for the pre-Volcker period.

Table 2. Estimation Results: Pre-Volcker Period

\begin{tabular}{ccccc}
\hline & \multicolumn{2}{c}{ GDP Deflator } & \multicolumn{2}{c}{$C P I$} \\
& $n=1$ & $n=4$ & $n=1$ & $n=4$ \\
\hline \hline$\widehat{\rho}$ & $0.72^{*}$ & $0.72^{*}$ & $0.74^{*}$ & $0.75^{*}$ \\
& $(0.04)$ & $(0.04)$ & $(0.06)$ & $(0.06)$ \\
$\widehat{\mu}_{\pi}$ & $0.24^{*}$ & $0.22^{*}$ & $0.11^{*}$ & 0.08 \\
& $(0.06)$ & $(0.06)$ & $(0.05)$ & $(0.05)$ \\
$\widehat{\mu}_{y}$ & $-0.49^{*}$ & $-0.52^{*}$ & $-0.37^{*}$ & -0.32 \\
& $(0.18)$ & $(0.19)$ & $(0.20)$ & $(0.22)$ \\
$R^{2}$ & 0.52 & 0.52 & 0.54 & 0.53 \\
$J$ & 0.77 & 0.77 & 0.65 & 0.61 \\
\hline
\end{tabular}

Notes: See notes to Table 1.

The feedback from changes in the output-gap is again negative and significant. Notably, the estimated coefficient $\widehat{\mu}_{\pi}$ on forward-looking inflation is significantly positive, suggesting 
that monetary policy during the pre-Volcker period was accommodating - higher expected inflation led to an increase in the money supply. Our findings are not sensitive to the chosen inflation measure with $\widehat{\mu}_{\pi}$ varying between 0.11 and 0.24 . The feedback from expected future inflation on the growth rate of the monetary aggregate appears to be less pronounced for longer horizons $(n=4)$.

Table 3 provides results obtained from estimating (1) using data for the VolckerGreenspan period. The most striking result discovered for this period concerns the inflation elasticity, which is now found to be significantly negative at all inflation measures and inflation target horizons. Thus, monetary policy as measured by a forward-looking money supply reaction function appeared to be more reactive than in the previous period. This conclusion principally corresponds to earlier results on the federal funds rate behavior where the Volcker-Greenspan era is found to exhibit more aggressive (anti-inflationary) interest rate adjustments (see Boivin 2006, Boivin and Giannoni, 2006, and Clarida et al., 2000). The reported estimates for $\mu_{\pi}$ range between -0.35 and -0.62 . Unlike in the pre-Volcker period, the supply of nonborrowed reserves now reacts somewhat stronger to expected inflation under a one year forward looking inflation horizon, suggesting that the Federal Reserve has shifted its focus towards longer target horizons. Estimates of $\mu_{y}$ indicate that the responses of nonborrowed reserves to the cyclical variable in both sub-periods are of comparable size. In fact, the average value for $\widehat{\mu}_{y}$ equals $-0.51(-0.34)$ for the GDP deflator (CPI) in the pre-Volcker period, which compares to a value of -0.60 $(-0.27)$ for the Volcker-Greenspan period.

Table 3. Estimation Results: Volcker-Greenspan Period

\begin{tabular}{ccccc}
\hline & \multicolumn{2}{c}{$G D P$ Deflator } & \multicolumn{2}{c}{$C P I$} \\
& $n=1$ & $n=4$ & $n=1$ & $n=4$ \\
\hline \hline$\widehat{\rho}$ & $0.91^{*}$ & $0.92^{*}$ & $0.95^{*}$ & $0.98^{*}$ \\
& $(0.02)$ & $(0.03)$ & $(0.07)$ & $(0.05)$ \\
$\widehat{\mu}_{\pi}$ & $-0.35^{*}$ & $-0.39^{*}$ & $-0.55^{*}$ & $-0.62^{*}$ \\
& $(0.15)$ & $(0.14)$ & $(0.05)$ & $(0.05)$ \\
$\widehat{\mu}_{y}$ & $-0.62^{*}$ & $-0.59^{*}$ & $-0.15^{*}$ & $-0.39^{*}$ \\
& $(0.14)$ & $(0.13)$ & $(0.04)$ & $(0.08)$ \\
$R^{2}$ & 0.73 & 0.73 & 0.69 & 0.71 \\
$J$ & 0.92 & 0.95 & 0.80 & 0.76 \\
\hline
\end{tabular}

Notes: See notes to Table 1.

In general, the goodness-of-fit statistics are satisfactory for both sub-samples, with the coefficient of determination ranging from 0.52 for the pre-Volcker period to 0.73 for the 
Volcker-Greenspan era. Hansen's J-test, which tests the validity of overidentifying restrictions, indicates that overall the null hypothesis that overidentifying restrictions are satisfied could not be rejected.

We additionally conducted sub-sample estimations of (1) based on two alternative output-gap measures as described above. Our findings, which are summarized in Table A1 and A2 (see appendix), illustrate the robustness of our benchmark results as reported in Table 1 and 2. In fact, both the signs and magnitudes of the estimated coefficients remain broadly unchanged. In line with our baseline estimates, there remains the striking subsample difference in the coefficient measuring the sensitivity of nonborrowed reserves to expected inflation: In the pre-Volcker period the coefficient $\widehat{\mu}_{\pi}$ only takes positive values, while it is always negative in the Volcker-Greenspan period. ${ }^{10}$

\section{$2.3 \quad$ Real-Time Estimates}

Our previously reported results indicate the robustness of the sub-sample findings across different specifications including alternative inflation and output-gap measures and different target horizons. To further assess the robustness of our results we examine the conduct of monetary policy under real-time data. Boivin (2006) and Orphanides (2001, 2002) have recently argued that the assessment of monetary policy based on ex post data produces a blurry picture, as central bankers are constrained by real-time information. Orphanides $(2002,2004)$, applying real-time data to a forward-looking interest rate reaction function, offers intriguing evidence that monetary policy during the pre-Volcker era was not accommodative at all but responded strongly to inflation forecasts. This finding evidently contrast those reported by Clarida et al. (2000).

A set of inflation forecasts suitable for analyzing the nature of real-time U.S. monetary policy is drawn from the so-called Greenbook. Greenbook forecasts are prepared by the staff of the Board of Governors for the meetings of the FOMC and have been used in a number of studies. ${ }^{11}$ Using the Greenbook forecasts in this context yield some important benefits. First, these forecasts are generated using information that was actually available at the time monetary policy decisions were made, providing a more precise view on monetary policy decisions. Second, since Greenbook forecasts are computed using a large set of information from a wide range of sources, the Fed forecasts might have an informational advantage over private sector forecasts. In fact, Romer and Romer (2000) have documented that Greenbook forecasts are exceptionally accurate compared to private-sector

\footnotetext{
${ }^{10}$ We also performed the estimations using non-borrowed reserves plus credit as the monetary aggregate. The results are qualitatively similar to our benchmark results. They are available from the authors upon request.

${ }^{11}$ See for example, Orphanides (2001, 2002, 2004), or Romer and Romer (2003). Information on the construction of these forecasts can be found in Reifschneider et al. (1997) and Orphanides (2004) who emphasize that forecasts are conditioned on an assumed path for the federal funds rate. Moreover, unlike other forecasts, which are often derived on the basis of econometric forecasting models, Greenbook forecasts comprise a large "judgmental" component.
} 
forecasts. ${ }^{12}$ Finally, since Greenbook forecasts account for possible structural changes of the economy, the time-varying nature of monetary policy is better described, making the analysis less susceptible to the Lucas critique as emphasized by Boivin (2006).

The first Greenbook forecasts were published in 1965. One shortcoming of the early forecasts is that observations were not consistently available and forecasts for longer horizons were not produced. Hence, for practical reasons our sample period covers the time horizon from the first quarter of 1968 to the last quarter of $1999 .{ }^{13}$ Using the Greenbook forecasts we estimate the structural relationship described by (1) for the pre-Volcker and Volcker-Greenspan era. Our set of instruments is similar to the set of previously used instruments and includes four lags of the growth rate of nonborrowed reserves, output-gap and inflation based on the GDP-deflator.

In accordance with our previous findings, the growth rate of nonborrowed reserves responds positively to rising inflation forecasts in the pre-Volcker era and negatively in the Volcker-Greenspan period, while the feedback from the real-time output-measure is always negative (see Table 4). Overall, these estimates clearly point to the existence of a shift in the conduct of U.S. monetary policy. Our findings contrast results which, by using real-time data to estimate forward looking interest rate reaction functions, do not detect a substantial shift in the structural part of U.S. post war monetary policy (see Orphanides, 2002).

\section{Table 4. Estimation Results based on Greenbook Forecasts}

\begin{tabular}{ccccc}
\hline & \multicolumn{2}{c}{ Pre-Volcker } & \multicolumn{2}{c}{ Volcker-Greenspan } \\
& $n=1$ & $n=4$ & $n=1$ & $n=4$ \\
\hline \hline$\widehat{\rho}$ & $0.56^{*}$ & $0.30^{*}$ & $0.87^{*}$ & $0.85^{*}$ \\
& $(0.03)$ & $(0.02)$ & $(0.03)$ & $(0.05)$ \\
$\widehat{\mu}_{\pi}$ & $0.12^{*}$ & 0.03 & $-0.20^{*}$ & $-0.25^{*}$ \\
& $(0.05)$ & $(0.05)$ & $(0.08)$ & $(0.06)$ \\
$\widehat{\mu}_{y}$ & $-1.79^{*}$ & $-1.82^{*}$ & $-0.84^{*}$ & $-0.63^{*}$ \\
& $(0.14)$ & $(0.15)$ & $(0.18)$ & $(0.14)$ \\
$R^{2}$ & 0.62 & 0.48 & 0.70 & 0.71 \\
$J$ & 0.94 & 0.96 & 0.76 & 0.76 \\
\hline
\end{tabular}

Notes: See notes to Table 1.

Real-time data seem to attribute a stronger role to the shorter inflation forecast horizon during the pre-Volcker era, while the longer forecast horizon becomes more impor-

\footnotetext{
${ }^{12}$ Moreover, Swanson (2004) assessing the Greenbook forecasts finds that the Fed's projections are largely rational.

${ }^{13}$ Note that Greenbook forecasts are published with a five year lag.
} 
tant during the Volcker-Greenspan period. Our estimates further indicate that ex post data overstate the (absolute value of the) inflation elasticity. In fact, the real-time estimates suggest that the Fed was less accommodating during the pre-Volcker era, while the anti-inflationary stance during the Volcker-Greenspan period was not as emphasized as the ex post data based estimations suggest. As regards the feedback from the real-time output-gap we discern two noteworthy results. First, monetary policy as described by our money supply reaction function exhibits in both periods a stronger feedback from realtime output-gap than from ex post output-gap. Second, during the pre-Volcker period monetary policy was very activist in its response to the output-gap, while the emphasis on the output-gap mitigated to some extent during the Volcker-Greenspan period. The latter finding is in principle consistent with Orphanides (2004), though his results are based on an interest rate reaction function. The difference in the estimated output-gap coefficients between real-time and ex post data might be due to the distorted estimation of the trend component of output (see Orphanides, 2002, 2004): These misperceptions about the trend component lead to a mismeasurement of the output-gap, which, if persistent over a period of time, might result in biased output-gap coefficients. As Orphanides (2004) points out these misperceptions concerning potential output were only much later understood, which may explain the striking difference in magnitude in the estimated coefficient for the real-time output-gap.

To summarize, the empirical analysis provides strong evidence for the supply of nonborrowed reserves to react systematically to expected inflation and the output-gap during the past four decades of Federal Reserve policy. The empirical results further indicate that monetary policy during the Volcker-Greenspan era had a proactive stance towards inflation stabilization. Our conclusion regarding the regime shift thus seems to be consistent with the empirical results in Clarida et al. (2000) who characterize the Volcker-Greenspan era as a highly reactive monetary policy regime. Conversely, in the pre-Volcker period, supply of nominal balances appeared to be mildly accommodating, lending support to the view that the Fed had a less anti-inflationary stance though aimed to stabilize output during that period. These main results are further robust to changes in the way expectations are modelled, i.e., the results are qualitatively unaffected when we apply real-time data as opposed to ex post data to describe the behavior of U.S. money supply.

\section{Money supply and macroeconomic stability}

In this section we apply a standard rational expectations model in order to assess the implementation of optimal monetary policy and to assess macroeconomic stability, i.e., equilibrium determinacy, for the case where the central bank controls the supply of money in a state contingent way. In the first part of this section we describe the model. In the second part we disclose the properties of an efficient money supply. In the third

part we derive the requirements for equilibrium determinacy under money supply reaction 
functions, which correspond to those used in Section 2.2.

\subsection{A macroeconomic model}

To facilitate comparisons with studies on macroeconomic stability under interest rate reaction functions, we use a consensus macroeconomic model, i.e., the standard New Keynesian model (see Clarida et al., 2000). This theoretical framework is based on a dynamic general equilibrium model with optimizing households and firms under rational expectations.

Our model is a linear approximation of a standard monetary sticky price model, which is comprehensively described in the textbooks of Walsh (2005) and Woodford (2003). It is a rational expectations equilibrium model with endogenous labor supply and an additively separable CES utility function. The production of goods exhibits constant returns of scale with labor as the single input. Goods prices are imperfectly flexible, i.e., monopolistically competitive firms set prices in a staggered way (see Calvo, 1983). Money demand is further induced by real balances entering the utility function. Uncertainty is due to costpush shocks $\varphi_{t}$, which might, for example, originate in exogenous shifts in price or wage mark-ups. Given that these types of shocks are distortionary, macroeconomic fluctuations lead to welfare losses.

Since the purpose of the paper is to assess monetary stabilization policy, we restrict our attention to local equilibria that converge to a long-run equilibrium. Following large parts of the literature, the equilibrium conditions are log-linearized at the steady state. We further assume that the support of aggregate shocks is sufficiently small and that the steady state gross nominal interest rate exceeds one, $\bar{R}>1$. In a neighborhood of the steady state the equilibrium sequences are then approximated by the solutions to the linearized equilibrium conditions, where $\widehat{z}_{t}$ denotes the percent deviation of a generic variable $z_{t}$ from its steady state value $z, \widehat{z}_{t}=\left(z_{t}-z\right) / z .^{14}$

A rational expectations equilibrium consists of a set of sequences for inflation $\widehat{\pi}_{t}$ (where $\left.\pi_{t}=P_{t} / P_{t-1}\right)$, output $\widehat{x}_{t}$, (end-of-period) real balances $\widehat{m}_{t}$, and the nominal interest rate, $\left\{\widehat{\pi}_{t}, \widehat{x}_{t}, \widehat{m}_{t}, \widehat{R}_{t}\right\}_{t=0}^{\infty}$ that converge to the steady state and satisfy

$$
\begin{aligned}
\widehat{\pi}_{t} & =\omega \widehat{x}_{t}+\beta E_{t} \widehat{\pi}_{t+1}+\widehat{\varphi}_{t}, \\
\sigma \widehat{x}_{t} & =\sigma E_{t} \widehat{x}_{t+1}-\left(\widehat{R}_{t}-E_{t} \widehat{\pi}_{t+1}\right), \\
\widehat{m}_{t} & =\widehat{x}_{t}-[\sigma(\bar{R}-1)]^{-1} \widehat{R}_{t},
\end{aligned}
$$

with $\beta \in(0,1), \sigma>0$, and $\omega>0$, and a monetary policy, for a given sequence of shocks $\left\{\widehat{\varphi}_{t}\right\}_{t=0}^{\infty}$ satisfying $\widehat{\varphi}_{t}=\rho_{\varphi} \widehat{\varphi}_{t-1}+\varepsilon_{t}$, where $\rho_{\varphi} \in[0,1)$ and $E_{t-1} \varepsilon_{t}=0$, and given $m_{-1}=M_{-1} / P_{-1}>0$, where $M$ denotes nominal balances and $P$ the aggregate price level.

\footnotetext{
${ }^{14}$ The derivation of these conditions can for example be found in Woodford (2005) or in Schabert (2005). For simplicity we assume an identical elasticity of intertemporal substitution for consumption and real balances, $1 / \sigma$.
} 
To disclose the main principles for the impact of money supply on macroeconomic stability, we assume that the stock of monetary aggregates $M_{t}$ that provides transactions services in the goods market is tied to the stock of high-powered money $H_{t}$, for example, via reserve requirements. In particular, we assume that the money multiplier does not change endogenously, which we view as a reasonable approximation at business cycle frequencies. Since we focus on the structural relations between money supply and macroeconomic aggregates, we further disregard shocks to the multiplier, for convenience. In log-linearized form the real values of both aggregates then simply satisfy $\widehat{m}_{t}=\widehat{h}_{t}$, where $h_{t}=H_{t} / P_{t}$, implying that the central bank is able to control the growth rate of nominal money $\widehat{\mu}_{t}=$ $\widehat{m}_{t}-\widehat{m}_{t-1}+\widehat{\pi}_{t}$ directly by adjusting the supply of high powered money $\left(H_{t} / H_{t-1}\right)$.

For the subsequent analysis, we consider the cases where money supply either responds to the current inflation rate $(n=0)$ or to the one-period ahead expected rate of inflation $(n=1)$, like in related studies on interest rate feedback rules. We assume that money supply can be summarized by a forward-looking reaction function, according to which the money growth rate $\mu_{t}$ is adjusted in response to changes in expected future inflation, the output-gap, and the exogenous state:

$$
\widehat{\mu}_{t}=\bar{\mu}_{\pi} E_{t} \widehat{\pi}_{t+n}+\bar{\mu}_{y} \widehat{x}_{t}+\Xi_{t}, \quad \text { where } n \in\{0,1\},
$$

where $\Xi_{t}=\Xi\left(\hat{\varphi}_{t}\right)$ is a linear function of the cost-push shock's current realization. The type of reaction function in (7) for example accords to Evans and Honkapohja's (2003) specification for forward-looking interest rate feedback rules, which can uniquely implement an optimal monetary policy. Since we do not model inertial instrument adjustments explicitly, the feedback coefficients $\bar{\mu}_{\pi}$ and $\bar{\mu}_{y}$ correspond to the "long-run" feedback coefficients $\mu_{\pi} /(1-\rho)$ and $\mu_{y} /(1-\rho)$ in the empirical money supply specification (1). This relationship will be used below to disclose whether the Federal Reserve's money supply has been associated with a unique or multiple rational expectations equilibria.

\subsection{Implementing optimal policy with money supply adjustments}

Before we turn to the main part of the theoretical analysis, namely, the assessment of macroeconomic stability under forward-looking money supply reaction functions (7), we characterize efficient money supply. For this, we adopt Woodford's (2003) second-order approximation of household welfare at the steady state. Since we are interested in monetary stabilization policy, we abstract from long-run distortions and we assume that an unspecified lump-sum financed subsidy eliminates average distortions due to monopolistic competition. Output deviations from the steady state then represent output-gaps, since any deviation of current output from its steady state value is induced by a distortionary shock $\widehat{\varphi}_{t}$. We further assume that the distortions due to transactions frictions are negligible, such that a second-order Taylor-expansion of household welfare and of the private sector equilibrium conditions at the undistorted steady state leads to the following central 
bank objective (see Walsh, 2005, or Woodford, 2003):

$$
\min E_{0} \sum_{t=0}^{\infty} \beta^{t} \frac{1}{2}\left(\hat{\pi}_{t}^{2}+\frac{\omega}{\epsilon} \widehat{x}_{t}^{2}\right),
$$

where $\epsilon>1$ denotes the elasticity of substitution between differentiated intermediate goods. The optimal plan of the central bank acting under commitment in a timeless perspective is then known to be characterized by (4)-(6) and the central bank's first order condition $\widehat{x}_{t}-\widehat{x}_{t-1}=-\epsilon \widehat{\pi}_{t} \forall t \geq 0$ (see Clarida et al., 1999 or Woodford, 2003). This plan can in principle be implemented in different ways, e.g. by an interest rate reaction function or by a state contingent money supply. It can be shown that a forward looking money supply reaction function can implement the optimal plan.

Proposition 1 The central bank can implement its optimal commitment plan under a timeless perspective if it supplies money according to (7) for $n=1$ with

$$
\begin{aligned}
& \bar{\mu}_{\pi}=\frac{\sigma-1}{\sigma} \beta<1, \\
& \bar{\mu}_{y}=-\frac{(\sigma-1) \beta+\sigma(\epsilon-1)}{(1-\beta) \sigma} \omega<0,
\end{aligned}
$$

and $\Xi_{t}=-\gamma \sigma\left(\widehat{x}_{t}-E_{t-1} \widehat{x}_{t}\right)-\gamma\left(\widehat{\pi}_{t}-E_{t-1} \widehat{\pi}_{t}\right)-[(\epsilon-1)+\gamma(\sigma \epsilon-1)] \widehat{\varphi}_{t}$. Under rational expectations $\Xi\left(\widehat{\varphi}_{t}\right)=\alpha \widehat{\varphi}_{t}$ with $\alpha=-(\epsilon-1)-\frac{\beta(\sigma \epsilon-1)}{\sigma(1-\beta)} \frac{\left(\epsilon \omega-\beta \rho_{\varphi}\right)+\beta\left(1-\delta_{1}\right)}{\epsilon \omega+\beta\left(1-\delta_{1}\right)+\left(1-\beta \rho_{\varphi}\right)}$, where $\delta_{1}=$ $\frac{1}{2 \beta}\left\{\kappa-\beta\left[(\kappa / \beta)^{2}-4 \beta^{-1}\right]^{1 / 2}\right\} \in(0,1)$ and $\kappa=1+\beta+\epsilon \omega$.

Proof. See appendix 5.2.

According to proposition 1, a forward-looking money supply reaction function (7) can be consistent with the central bank's optimal commitment plan under a timeless perspective. The feedback coefficients of the particular reaction function characterized in the proposition demand that nominal balances respond by less than one for one with expected inflation, $\bar{\mu}_{\pi}<1$, and decrease with the output-gap, $\bar{\mu}_{y}<0$. It should be noted that this reaction function does not feature a lagged indicator (e.g. lagged output-gap), which is necessary for an interest rate reaction function to be able to implement the commitment solution (see Clarida et al., 1999, or Woodford, 2003). The reason is that the instrument on the left hand side of $(7)$ already contains a backward-looking element $\left(\widehat{m}_{t-1}\right)$, which is sufficient to implement history dependent equilibrium sequences (see Schabert, 2005).

A closer look at the coefficient $\bar{\mu}_{\pi}=\frac{\sigma-1}{\sigma} \beta$ further shows that the inflation feedback can either be positive or negative, depending on the intertemporal elasticity of substitution of consumption. If households are very risk-averse and highly prefer a smooth consumption paths (large $\sigma$ ), the central bank's trade-off between the stabilization of inflation and output shift towards the latter. As a consequence, the inflation feedback is positive. 
Otherwise, if households care less about consumption smoothing $(\sigma<1)$, the inflation feedback is negative. In any case, the central bank should supply money in a way that ensures real balances to decrease with inflation $\left(\bar{\mu}_{\pi}<1\right)$. However, a positive or a negative sign of the inflation feedback can be consistent with an optimal money supply, depending on the households' degree of risk aversion. Since our estimates for the output-gap feedback are always negative (see Section 2) and there is no clear consensus on the value for $\sigma$, money supply under both Federal Reserve regimes was in principle consistent with optimal policy.

\subsection{Money supply and equilibrium determinacy}

Next we want to examine the equilibrium determinacy properties of the model under forward-looking money supply reaction functions (7) with unrestricted feedback coefficients $\bar{\mu}_{\pi}$ and $\bar{\mu}_{y}$. The model (4)-(7) exhibits one backward-looking element, i.e., the predetermined state variable $\widehat{m}_{t-1}$. Equilibrium uniqueness therefore requires that there exists exactly one stable eigenvalue. It can be shown that the existence of exactly one stable and positive eigenvalue requires a money supply reaction function (7) for $n=1$ and $n=0$ to satisfy (see appendix 5.3)

$$
\bar{\mu}_{\pi}+\bar{\mu}_{y} \frac{1-\beta}{\omega}<1
$$

which in terms of the feedback coefficients in the presence of partial adjustments reads $\mu_{\pi}+$ $\mu_{y} \frac{1-\beta}{\omega}<1-\rho$ (see Section 2). Condition (8) demands the weighted sum of the feedback coefficients in (7) to be smaller than one. ${ }^{15}$ This condition evidently corresponds to the well known Taylor-principle which requires the weighted sum of the long-run coefficients of an interest rate feedback rule to be larger than one (see Woodford, 2001).

To get an intuition for this "inverted" Taylor-principle consider the case $\mu_{y}=0$. If the economy is hit by a cost push shock $\widehat{\varphi}_{t}>0$, inflation tends to rise, leading to a decreasing real value of money for $\bar{\mu}_{\pi}<1$. In this case, the output-gap will be narrowed (see 6 ), which stabilizes inflation by (4). Otherwise, $\bar{\mu}_{\pi}>1$, money supply is accommodative such that real balances grow. This tends to reduce the interest rate and to raise aggregate demand, such that price pressure further increases. Due to this mechanism money supply policy can render multiple equilibria or instability (i.e. non-existence of convergent equilibrium sequences) possible. It should, however, be noted that condition (8) just ensures that there exists exactly one positive stable eigenvalue, leading to a non-oscillatory equilibrium solution. Hence, there might also exist alternative equilibrium solutions (characterized by one positive and one negative stable eigenvalue). The following proposition presents determinacy conditions for current looking $(n=0)$ and forward looking $(n=1)$ money supply reaction functions $(7) .{ }^{16}$

\footnotetext{
${ }^{15}$ A similar condition is shown in Schabert (2006) to be necessary and sufficient for determinacy in a continuous time sticky price model.

${ }^{16}$ The unique equilibrium solution is in both cases non-oscillatory. The determinacy conditions for case
} 
Proposition 2 Suppose that the central bank adjusts the supply of money according to (7). Then, the equilibrium exhibits determinacy if and only if (8) and either $\bar{\mu}_{\pi}+\bar{\mu}_{y} \frac{1+\beta}{\omega}<1+\Delta$ for $n=0$ or $-\bar{\mu}_{\pi}+\bar{\mu}_{y} \frac{1+\beta}{\omega}<1+\Delta$ for $n=1$, where $\Delta=2(\gamma \omega+(2 \sigma \gamma+1)(1+\beta)) / \omega>0$ and $\gamma=[\sigma(\bar{R}-1)]^{-1}$.

Proof. See appendix 5.3.

Given the conditions in proposition 2 we can now easily check the determinacy implications of the Fed's money supply. For this we set the feedback coefficients in (7) equal to the point estimates in Section 2.2, $\bar{\mu}_{\pi}=\widehat{\mu}_{\pi} /(1-\widehat{\rho})$ and $\bar{\mu}_{y}=\widehat{\mu}_{y} /(1-\widehat{\rho})$. Since the feedback from output-gap and inflation has been negative in the Volcker-Greenspan period, condition (8) is evidently satisfied. The additional conditions given in proposition 2 are further satisfied for $n=0$ and for any reasonable set of parameter values also for $n=1$. $^{17}$ Thus, our analysis unambiguously implies that money supply in the Volcker-Greenspan period has been associated with equilibrium uniqueness.

To assess the determinacy implications of the pre-Volcker policy, we have to take a closer look at the point estimates presented in Table 2-4. Since the output-gap feedback is always negative, condition (8) can be violated only if the long-run inflation feedback $\widehat{\mu}_{\pi} /(1-\widehat{\rho})$ exceeds one. Computing these values for all specifications in Section 2 however shows that $\widehat{\mu}_{\pi} /(1-\widehat{\rho})$ is always strictly smaller than one. For example, its maximum value is 0.86 for ex post data (see table 2 ) and 0.27 for real time data (see table 4 ). Hence, condition (8) cannot be violated. Moreover, the additional conditions given in proposition 2 are always satisfied.

Corollary 3 If the feedback coefficients $\bar{\mu}_{\pi}$ and $\bar{\mu}_{y}$ for the money supply reaction function (7) equal the long-run feedback coefficients estimated for the Pre-Volcker period, $\bar{\mu}_{\pi}=$ $\widehat{\mu}_{\pi} /(1-\widehat{\rho})$ and $\bar{\mu}_{y}=\widehat{\mu}_{y} /(1-\widehat{\rho})$, the equilibrium never exhibits indeterminacy.

Thus, we can summarize that a money supply that is characterized by feedback coefficients that are equal to the point estimates obtained for the pre-Volcker period, the rational expectations equilibrium is uniquely determined. This result holds regardless of the sample period and whether we use the estimates for revised data or for real-time data. Thus our analysis of the stability implications of money supply regimes leads to a different conclusion than previous studies focussing on interest rate rules: Pre-Volcker Federal Reserve policy has not been associated with multiple equilibria and therefore did not allow for macroeconomic fluctuations induced by non-fundamental shocks.

The difference between the determinacy results for money growth and interest rate policy corresponds to the property of nominal (in)determinacy under money growth (interest

$n=0$ have already been derived in Schabert (2005).

${ }^{17}$ In particular, $\Delta$ takes very high values for standard values for the interest rate elasticity of money demand, $\gamma(\bar{R}-1)$, regardless whether the degree of price rigidities is calibrated to match micro or macro evidence (see Bils and Klenow, 2004, Gali and Gertler, 1999). 
rate) policy, which has been stressed by Sargent and Wallace (1975). ${ }^{18}$ While a constant money growth policy facilitates nominal determinacy under perfectly flexible prices, it causes beginning-of-period real balances to be relevant for equilibrium determination when prices are not perfectly flexible. The predetermined value of real money then serves as a equilibrium selection criterion, which rules out additional solutions that might allow for endogenous fluctuations. As shown by Black (1974), the determinacy implications under money growth policy can change if the central bank adjusts money with inflation. In particular, he shows that price level indeterminacy prevails if real balances grow with inflation $\left(\mu_{\pi}>1\right)$. Thus, determinacy is not guaranteed by any money supply policy, but requires real balances to decrease with inflation. According to our results, Federal Reserve policy always satisfied this requirement and thereby never allowed for macroeconomic instability.

\section{Conclusion}

In this paper we provide empirical evidence that the Federal Reserve's money supply, i.e., the supply of nonborrowed reserves, has responded to changes in expected inflation and the output-gap. Estimates of forward-looking money supply reaction functions for the pre1979 (pre-Volcker) and the post-1979 (Volcker-Greenspan) period reveal that money supply responded negatively to a widening output-gap in both periods. In contrast, money supply responses to changes in expected inflation exhibit considerable differences between both regimes. The Volcker-Greenspan regime was characterized by a highly anti-inflationary policy indicated by a significantly negative feedback from expected inflation. Conversely, we find a positive feedback from expected inflation for the pre-Volcker regime, indicating a less anti-inflationary policy stance. These findings thus confirm related evidence based on the analysis of the federal funds rate, namely that the Federal Reserve policy in the preVolcker era was conducted in a less inflation stabilizing way than in the Volcker-Greenspan era. Moreover, our findings are supported when the analysis is conducted with real-time data.

We further provide a theoretical analysis of the stabilization properties of forwardlooking money supply reaction functions in a standard sticky price model. The key requirement is that money supply has to be associated with real balances that decrease with inflation in order to ensure macroeconomic stability. Applying the results from the empirical analysis, money supply regimes characterized by the estimated feedback coefficients are shown to lead to a uniquely determined rational expectations equilibrium. According to this result, we cannot confirm the hypothesis of Clarida et al. (2000) that the preVolcker policy has contributed to high and volatile inflation rates in the 1970's by failing to pin down the rational expectations equilibrium. Viewed through a money supply lens

\footnotetext{
${ }^{18}$ See also Carlstrom and Fuerst $(2001,2003)$ and Schabert (2006) for different determinacy implications of money growth and interest rate rules.
} 
Federal Reserve policy in the pre-1979 period has been sufficiently reactive to guarantee equilibrium determinacy and to rule out expectations driven (endogenous) fluctuations. 


\section{Appendix}

\subsection{Estimates for alternative output-gap measures}

Table A1. Estimation Results Based on Unemployment

\begin{tabular}{ccccc}
\hline & \multicolumn{2}{c}{ Pre-Volcker } & \multicolumn{2}{c}{ Volcker-Greenspan } \\
& $n=1$ & $n=4$ & $n=1$ & $n=4$ \\
\hline \hline$\widehat{\rho}$ & $0.71^{*}$ & $0.71^{*}$ & $0.91^{*}$ & $0.90^{*}$ \\
& $(0.05)$ & $(0.06)$ & $(0.02)$ & $(0.03)$ \\
$\widehat{\mu}_{\pi}$ & $0.12^{*}$ & 0.10 & $-0.34^{*}$ & $-0.31^{*}$ \\
& $(0.06)$ & $(0.06)$ & $(0.15)$ & $(0.17)$ \\
$\widehat{\mu}_{y}$ & -0.23 & -0.23 & $-0.62^{*}$ & $-0.81^{*}$ \\
& $(0.25)$ & $(0.24)$ & $(0.15)$ & $(0.26)$ \\
$R^{2}$ & 0.54 & 0.53 & 0.73 & 0.73 \\
$J$ & 0.57 & 0.59 & 0.92 & 0.91 \\
\hline
\end{tabular}

Notes: Estimations are conducted using the alternative output gap measure based on the deviation of unemplyoment rate from a fitted quadratic function of time. See notes to Table 1.

Table A2. Estimation Results based on Detrended Output

\begin{tabular}{ccccc}
\hline & \multicolumn{2}{c}{ Pre-Volcker } & \multicolumn{2}{c}{ Volcker-Greenspan } \\
& $n=1$ & $n=4$ & $n=1$ & $n=4$ \\
\hline \hline$\widehat{\rho}$ & $0.76^{*}$ & $0.83^{*}$ & $0.91^{*}$ & $0.96^{*}$ \\
& $(0.03)$ & $(0.04)$ & $(0.04)$ & $(0.03)$ \\
$\widehat{\mu}_{\pi}$ & $0.25^{*}$ & $0.10^{*}$ & $-0.50^{*}$ & $-0.49^{*}$ \\
& $(0.04)$ & $(0.04)$ & $(0.17)$ & $(0.17)$ \\
$\widehat{\mu}_{y}$ & $-0.24^{*}$ & $-0.18^{*}$ & $-0.46^{*}$ & $-0.47^{*}$ \\
& $(0.07)$ & $(0.08)$ & $(0.15)$ & $(0.14)$ \\
$R^{2}$ & 0.52 & 0.51 & 0.72 & 0.72 \\
$J$ & 0.42 & 0.41 & 0.92 & 0.95 \\
\hline
\end{tabular}

Notes: Estimations are conducted using the alternative output gap measure based on the deviation of (log) GDP from a fitted quadratic function of time. See notes to Table 1. 


\subsection{Proof of proposition 1}

In order to establish the claim made in the proposition, we derive feedback coefficients for a money supply reaction function of the type (7) that is consistent with the central bank's commitment plan under a timeless perspective. The plan is a set of sequences $\left\{\widehat{x}_{t}, \widehat{\pi}_{t}\right\}_{t=0}^{\infty}$ satisfying (4)-(6), and $\widehat{x}_{t}-\widehat{x}_{t-1}=-\epsilon \widehat{\pi}_{t} \forall t \geq 0$. Eliminating the interest rate with the money demand condition $\widehat{m}_{t}=\widehat{x}_{t}-\gamma \widehat{R}_{t}$, where $\gamma=[\sigma(\bar{R}-1)]^{-1}$, in (5) leads to $\widehat{m}_{t}=(1+\gamma \sigma) \widehat{x}_{t}-\gamma \sigma E_{t} \widehat{x}_{t+1}-\gamma E_{t} \widehat{\pi}_{t+1}$, which for $t-1$ reads $\widehat{m}_{t-1}=(1+\gamma \sigma) \widehat{x}_{t-1}-$ $\gamma \sigma E_{t-1} \widehat{x}_{t}-\gamma E_{t-1} \widehat{\pi}_{t}$. Combining these conditions shows that private sector behavior implies the following equilibrium behavior for the money growth rate, $\widehat{\mu}_{t}=\widehat{m}_{t}+\widehat{\pi}_{t}-\widehat{m}_{t-1}$ :

$$
\widehat{\mu}_{t}=\widehat{\pi}_{t}+(1+\gamma \sigma)\left(\widehat{x}_{t}-\widehat{x}_{t-1}\right)-\gamma \sigma\left(E_{t} \widehat{x}_{t+1}-E_{t-1} \widehat{x}_{t}\right)-\gamma\left(E_{t} \widehat{\pi}_{t+1}-E_{t-1} \widehat{\pi}_{t}\right) .
$$

Using the central bank's first order condition for $t, \widehat{x}_{t}-\widehat{x}_{t-1}=-\epsilon \widehat{\pi}_{t}$, as well as for $t+1$ and taking expectations, $E_{t} \widehat{x}_{t+1}=-\epsilon E_{t} \widehat{\pi}_{t+1}+\widehat{x}_{t}$, one can rewrite the equilibrium condition for the money growth rate as

$\widehat{\mu}_{t}=-[(\epsilon-1)+\gamma(\sigma \epsilon-1)] \widehat{\pi}_{t}+\gamma(\sigma \epsilon-1) E_{t} \widehat{\pi}_{t+1}-\gamma \sigma\left(\widehat{x}_{t}-E_{t-1} \widehat{x}_{t}\right)-\gamma\left(\widehat{\pi}_{t}-E_{t-1} \widehat{\pi}_{t}\right)$.

Further, eliminating the current inflation rate with (4) one obtains the equilibrium money growth rate as the following function of expected inflation, the current output-gap, and the exogenous state

$$
\widehat{\mu}_{t}=\frac{\sigma-1}{\sigma} \beta E_{t} \widehat{\pi}_{t+1}-\frac{(\sigma-1) \beta+\sigma(\epsilon-1)}{(1-\beta) \sigma} \omega \widehat{x}_{t}+\Xi_{t}
$$

where we used that $\gamma=(\sigma(\bar{R}-1))^{-1}=\beta /[\sigma(1-\beta)]$ holds at an undistorted steady state. Note that $\Xi_{t}$ contains expectation errors and is a function of the exogenous state only and is given by $\Xi\left(\widehat{\varphi}_{t}\right)=-\gamma \sigma\left(\widehat{x}_{t}-E_{t-1} \widehat{x}_{t}\right)-\gamma\left(\widehat{\pi}_{t}-E_{t-1} \widehat{\pi}_{t}\right)-[(\epsilon-1)+\gamma(\sigma \epsilon-1)] \widehat{\varphi}_{t}$. In order to identify the reduced for of $\Xi_{t}$ under rational expectations, we further derive the solution for the output-gap and inflation sequences under the central bank's plan, i.e., for a set $\left\{\widehat{x}_{t}, \widehat{\pi}_{t}\right\}$ satisfying $\widehat{x}_{t}-\widehat{x}_{t-1}=-\epsilon \widehat{\pi}_{t}$ and $\widehat{\pi}_{t}=\omega \widehat{x}_{t}+\beta E_{t} \widehat{\pi}_{t+1}+\widehat{\varphi}_{t}$. Since there exists one backward-looking element, $\widehat{x}_{t-1}$, the fundamental solution for the output-gap and inflation takes the general form

$$
\widehat{x}_{t}=\delta_{1} \widehat{x}_{t-1}+\delta_{2} \widehat{\varphi}_{t} \text { and } \widehat{\pi}_{t}=\delta_{3} \widehat{x}_{t-1}+\delta_{4} \widehat{\varphi}_{t}
$$

Applying the method of undetermined coefficients, one gets the following expressions for $\delta_{2}, \delta_{3}$, and $\delta_{4}$ (as a function of the eigenvalue $\delta_{1}$ )

$$
\begin{aligned}
& \delta_{2}=-\epsilon \delta_{4}<0, \delta_{3}=\left(1-\delta_{1}\right) / \epsilon>0, \\
& \delta_{4}=\frac{1}{\epsilon \omega+\beta\left(1-\delta_{1}\right)+\left(1-\beta \rho_{\varphi}\right)}>0
\end{aligned}
$$


There are two solution candidates for the eigenvalue $\delta_{1}, \delta_{1}=\frac{1}{2} \phi \pm \frac{1}{2} \sqrt{-4 \beta^{-1}+\phi^{2}}$, where $\phi=\frac{1+\beta+\epsilon \omega}{\beta}>1 / \beta$. It can easily be shown that one solution exceeds one, while the other lies between zero and one. Hence, the single feasible solution for $\delta_{1}$ that is associated with a locally stable equilibrium is given by

$$
\delta_{1}=\frac{1}{2} \frac{1+\beta+\epsilon \omega}{\beta}-\frac{1}{2} \sqrt{-4 \beta^{-1}+\left(\frac{1+\beta+\epsilon \omega}{\beta}\right)^{2}} .
$$

where $\delta_{1} \in(0,1)$. Thus, the fundamental solution is the unique solution to the central bank's plan. Using the fundamental solution to write the forecast errors as $\widehat{x}_{t}-E_{t-1} \widehat{x}_{t}=$ $\delta_{2} \widehat{\varphi}_{t}$ and $\widehat{\pi}_{t}-E_{t-1} \widehat{\pi}_{t}=\delta_{4} \widehat{\varphi}_{t}$, we can finally write $\Xi_{t}=\Xi\left(\widehat{\varphi}_{t}\right)$ solely as a function of the exogenous state

$$
\Xi\left(\widehat{\varphi}_{t}\right)=\alpha \widehat{\varphi}_{t}, \quad \text { where } \alpha=-(\epsilon-1)-\frac{\beta(\sigma \epsilon-1)}{\sigma(1-\beta)} \frac{\left(\epsilon \omega-\beta \rho_{\varphi}\right)+\beta\left(1-\delta_{1}\right)}{\epsilon \omega+\beta\left(1-\delta_{1}\right)+\left(1-\beta \rho_{\varphi}\right)}
$$

Hence, the central bank's plan is consistent with a forward-looking money supply reaction function satisfying $\widehat{\mu}_{t}=\overline{\mu_{\pi}} E_{t} \widehat{\pi}_{t+1}+{\overline{\mu_{y}}}_{t}+\alpha \widehat{\varphi}_{t}$, where $\overline{\mu_{\pi}}=\frac{\sigma-1}{\sigma} \beta<1$ and $\overline{\mu_{y}}=-\frac{(\sigma-1) \beta+\sigma(\epsilon-1)}{(1-\beta) \sigma} \omega<0$.

\subsection{Proof of proposition 2}

To proof the first part of the proposition, the deterministic version of the model with a money demand $\widehat{m}_{t}=\widehat{x}_{t}-\gamma \widehat{R}_{t}$ and money supply (7) with $\rho=0$ is written as

$$
\left(\begin{array}{c}
\widehat{m}_{t} \\
E_{t} \widehat{\pi}_{t+1} \\
E_{t} \widehat{x}_{t+1}
\end{array}\right)=\mathbf{A}\left(\begin{array}{c}
\widehat{m}_{t-1} \\
\widehat{\pi}_{t} \\
\widehat{x}_{t}
\end{array}\right) \text {, where } \mathbf{A}=\left(\begin{array}{ccc}
0 & \beta & 0 \\
1 / \gamma & 1 & \sigma \\
1 & -\mu_{\pi} & 0
\end{array}\right)^{-1}\left(\begin{array}{ccc}
0 & 1 & -\omega \\
0 & 0 & \sigma+\gamma^{-1} \\
1 & -1 & \mu_{y}
\end{array}\right)
$$

where $\gamma=[\sigma(\bar{R}-1)]^{-1}>0$. The characteristic polynomial of $\mathbf{A}$, which is given by

$$
\begin{aligned}
K_{n=1}(X)= & X^{3}-X^{2} \frac{\beta+\sigma \gamma+\gamma \omega+2 \sigma \beta \gamma+\omega \mu_{\pi}-\beta \mu_{y}}{\sigma \beta \gamma} \\
& -X \frac{\mu_{y}-\omega-2 \sigma \gamma-\gamma \omega-\beta-\sigma \beta \gamma-1}{\sigma \beta \gamma}-\frac{\sigma \gamma+1}{\sigma \beta \gamma},
\end{aligned}
$$

takes the following values at 0,1 and -1

$$
\begin{aligned}
K_{n=1}(0) & =-(\sigma \gamma+1) /(\sigma \beta \gamma)<-1, \\
K_{n=1}(1) & =\gamma^{-1} \beta^{-1} \sigma^{-1}\left(\omega-\mu_{y}-\omega \mu_{\pi}+\beta \mu_{y}\right), \\
K_{n=1}(-1) & =\gamma^{-1} \beta^{-1} \sigma^{-1}\left(\mu_{y}(1+\beta)-\omega \mu_{\pi}-\omega-2(\gamma \omega+(2 \sigma \gamma+1)(1+\beta))\right) .
\end{aligned}
$$

Since $K_{n=1}(0)=-\operatorname{det}(\mathbf{A})=-(\sigma \gamma+1) /(\sigma \beta \gamma)<-1$, there exists at least one unstable positive root, while there is exactly one stable positive root if (8) is satisfied, such that 
$K_{n=1}(1)>0$. Thus, there is exactly one stable root (indicating determinacy) if (8) and $K_{n=1}(-1)<0$ which requires

$$
-\mu_{\pi}+\mu_{y} \frac{1+\beta}{\omega}<1+\frac{2(\gamma \omega+(2 \sigma \gamma+1)(1+\beta))}{\omega} .
$$

To establish the second part of the proposition $(n=0)$, we use that the characteristic polynomial of the changed matrix $\mathbf{A}$ is

$$
\begin{aligned}
K_{n=0}(X)= & X^{3}-X^{2} \frac{\beta+\sigma \gamma+\gamma \omega+2 \sigma \beta \gamma-\beta \mu_{y}}{\sigma \beta \gamma} \\
& -X \frac{\mu_{y}-\omega-2 \sigma \gamma-\gamma \omega-\beta-\sigma \beta \gamma+\omega \mu_{\pi}-1}{\sigma \beta \gamma}-\frac{\sigma \gamma+1}{\sigma \beta \gamma} .
\end{aligned}
$$

Since $K_{n=0}(0)=K_{n=1}(0)<-1$, there exists at least one unstable positive root, while there is exactly one stable positive root if (8) is satisfied, such that $K_{n=0}(1)=K_{n=0}(1)>0$. Thus, there is exactly one stable root (indicating stability and uniqueness) if (8) and $K_{n=0}(-1)=\left[\omega \mu_{\pi}+\mu_{y}(1+\beta)-\omega-2((1+2 \sigma \gamma)(1+\beta)+\gamma \omega)\right] /(\sigma \beta \gamma)<0$ which requires

$$
\mu_{\pi}+\mu_{y} \frac{1+\beta}{\omega}<1+\frac{2((1+2 \sigma \gamma)(1+\beta)+\gamma \omega)}{\omega} .
$$

which is ensured by (8) if $\mu_{y}<0$. This completes the proof.

\section{References}

Bernanke, B. S., and I. Mihov, 1998, Measuring Monetary Policy, Quarterly Journal of Economics 113, 869-902.

Bils, M., and P. Klenow, 2004, Some Evidence on the Importance of Sticky Prices, Journal of Political Economy 112, 947-985.

Black, F., 1974, Uniqueness of the Price Level in Monetary Growth Models with Rational Expectations, Journal of Economic Theory 7, 53-65.

Boivin, J., 2006, Has U.S. Monetary Policy Changed? Evidence from Drifting Coefficients and Real-Time Data, Journal of Money, Credit and Banking, forthcoming.

Boivin, J., and M.P. Giannoni, 2006, Has Monetary Policy Become More Effective?, Review of Economics and Statistics, forthcoming

Calvo, G., 1983, Staggered Prices in a Utility-Maximizing Framework, Journal of Monetary Economics 12, 383-398.

Carlstrom C.T., and T.S. Fuerst, 2001, Timing and Real Indeterminacy in Monetary Models, Journal of Monetary Economics 47, 285-298. 
Carlstrom C.T., and T.S. Fuerst, 2003, Money Growth Rules and Price Level Determinacy, Review of Economic Dynamics 6, 263-275.

Carpenter S., and S. Demiralp, 2006, The Liquidity Effect in the Federal Funds Market: Evidence from Daily Open Market Operations, Journal of Money, Credit, and Banking, forthcoming.

Christiano, L.J., M. Eichenbaum, and C. Evans, 1999, Monetary Policy Shocks: What Have We Learned and to What End?, in: M. Woodford and J.B. Taylor (eds.), Handbook of Macroeconomics, North-Holland, Amsterdam, 65-148.

Clarida, R., J. Galí, and M. Gertler, 2000, Monetary Policy Rules and Macroeconomic Stability: Evidence and Some Theory, Quarterly Journal of Economics 115, 147-180.

Eichenbaum, M., 1992, Comments on 'Interpreting the Macroeconomic Time Series Facts: The Effects of Monetary Policy' by Christopher Sims, European Economic Review 36, 1001-1011.

Evans, G.W., and S. Honkapohja, 2003, Expectations and the Stability Problem for Optimal Monetary Policy, Review of Economic Studies 70, 807-824.

Friedman, B.M. and K.N. Kuttner, 1996, A Price Target for US Monetary Policy? Lessons form the Experience with Money Growth Targets, Brookings Papers on Economic Activity, 77-146.

Galí, J., and M. Gertler, 1999, Inflation Dynamics: A Structural Econometric Analysis, Journal of Monetary Economics 44, 195-222.

Goodfriend, M., 1991, Interest Rates and the Conduct of Monetary Policy, CarnegieRochester Conference Series on Public Policy 34, 7-30.

Hamilton, J.D., 1997, Measuring the Liquidity Effect, American Economic Review 87, 80-97.

Jeanne, O., 1998, Generating Real Persistent Effects of Monetary Policy: How much Nominal Rigidity Do We Really Need?, European Economic Review 42, 1009-1032.

King, R.G., and A.L. Wolman, 2004, Monetary Discretion, Pricing Complementarity and Dynamic Multiple Equilibria, Quarterly Journal of Economics 119, 1513-1553.

Leeper, E.M., and D.B. Gordon, 1992, In search of the liquidity effect, Journal of Monetary Economics, 29, 341-369. 
McCallum, B.T., and E. Nelson, 1999, An Optimizing IS-LM Specification for Monetary Policy and Business Cycle Analysis, Journal of Money, Credit, and Banking 31, 296-316.

Meulendyke, A.M., 1998, US Monetary Policy and Financial Markets, Federal Reserve Bank of New York, New York.

Orphanides, A., 2001, Monetary Policy Rules Based on Real-Time Data, American Economic Review 91, 964-985.

Orphanides, A., 2002, Monetary Policy Rules and the Great Inflation, American Economic Review 92, 115-120.

Orphanides, A., 2004, Monetary Policy Rules, Macroeconomic Stability, and Inflation: A View from the Trenches, Journal of Money, Credit and Banking, Vol. 36, No. 2, 151-175.

Reifschneider, D., D.J. Stockton, and D.W. Wilcox, 1997, Econometric Models and the Monetary Policy Process, Carnegie-Rochester Conference Series on Public Policy 47, 1-37.

Romer, C., and D. Romer, 2000, Federal Reserve Information and the Behavior of Interest Rates, American Economic Review 90, 429-457.

Romer, C., and D. Romer, 2003, Choosing the Federal Reserve Chair: Lessons from History, University of Berkeley Working Paper.

Sargent, T.J., and N. Wallace, 1975, "Rational" Expectations, the Optimal Monetary Policy Instrument, and the Optimal Money Supply Rule, Journal of Political Economy 83, 241-254.

Schabert, A., 2005, Discretionary Policy, Multiple Equilibria, and Monetary Instruments, CEPR Discussion Paper DP5400

Schabert, A., 2006, Central Bank Instruments, Fiscal Policy Regimes, and the Requirements for Equilibrium Determinacy, Review of Economic Dynamics 9, 2006, 742-762.

Strongin, S., 1995, The Identification of Monetary Policy Disturbances: Explaining the Liquidity Puzzle, Journal of Monetary Economics 34, 463-497.

Swanson, E.T., 2004, Signal Extraction and Non-certainty-Equivalence in Optimal Monetary Policy Rules, Macroeconomic Dynamics 8, 27-50.

Taylor, J.B., 1993, Discretion versus Policy Rules in Practice, Carnegie-Rochester Conference Series on Public Policy 39, 195-214. 
Taylor, J.B., 1999, An Historical Analysis of Monetary Policy Rules, in John B. Taylor (ed.) Monetary Policy Rules, University of Chicago Press.

Thornton, D.L., 2001, The Federal Reserve's Operating Procedure, Nonborrowed Reserves, Borrowed Reserves and the Liquidity Effect, Journal of Banking and Finance 25, 1717-1739.

Walsh, C., 2005, Monetary Theory and Policy, MIT Press.

Woodford, M., 2001, The Taylor Rule and Optimal Monetary Policy, American Economic Review, Papers \& Proceedings 91, 232-237.

Woodford, M., 2003, Interest and Prices: Foundations of a Theory of Monetary Policy, Princeton: Princeton University Press. 


\section{Swiss National Bank Working Papers published since 2004:}

2004-1 Samuel Reynard: Financial Market Participation and the Apparent Instability of Money Demand

2004-2 Urs W. Birchler and Diana Hancock: What Does the Yield on Subordinated Bank Debt Measure?

2005-1 Hasan Bakhshi, Hashmat Khan and Barbara Rudolf: The Phillips curve under state-dependent pricing

2005-2 Andreas M. Fischer: On the Inadequacy of Newswire Reports for Empirical Research on Foreign Exchange Interventions

2006-1 Andreas M. Fischer: Measuring Income Elasticity for Swiss Money Demand: What do the Cantons say about Financial Innovation?

2006-2 Charlotte Christiansen and Angelo Ranaldo: Realized Bond-Stock Correlation: Macroeconomic Announcement Effects

2006-3 Martin Brown and Christian Zehnder: Credit Reporting, Relationship Banking, and Loan Repayment

2006-4 Hansjörg Lehmann and Michael Manz: The Exposure of Swiss Banks to Macroeconomic Shocks - an Empirical Investigation

2006-5 Katrin Assenmacher-Wesche and Stefan Gerlach: Money Growth, Output Gaps and Inflation at Low and High Frequency: Spectral Estimates for Switzerland

2006-6 Marlene Amstad and Andreas M. Fischer: Time-Varying Pass-Through from Import Prices to Consumer Prices: Evidence from an Event Study with Real-Time Data

2006-7 Samuel Reynard: Money and the Great Disinflation

2006-8 Urs W. Birchler and Matteo Facchinetti: Can bank supervisors rely on market data? A critical assessment from a Swiss perspective

2006-9 Petra Gerlach-Kristen: A Two-Pillar Phillips Curve for Switzerland

2006-10 Kevin J. Fox and Mathias Zurlinden: On Understanding Sources of Growth and Output Gaps for Switzerland

2006-11 Angelo Ranaldo: Intraday Market Dynamics Around Public Information Arrivals

2007-1 Andreas M. Fischer, Gulzina Isakova and Ulan Termechikov: Do FX traders in Bishkek have similar perceptions to their London colleagues? Survey evidence of market practitioners' views 
2007-2 Ibrahim Chowdhury and Andreas Schabert: Federal Reserve Policy viewed through a Money Supply Lens 
Swiss National Bank Working Papers are also available at www.snb.ch, section Publications/Research Subscriptions or individual issues can be ordered at Swiss National Bank, Fraumünsterstrasse 8, CH-8022 Zurich, fax+41 4463181 14, E-mail library@snb.ch 